Contemporary Child Care Policy and Practice 
FEMINIST PERSPECTIVES ON DISABILITY

PRACTICE AND RESEARCH IN SOCIAL WORK: Postmodern Feminist

Perspectives (ed. with B. Featherstone, J. Fook and A. Rossiter)

VIOLENCE AND GENDER RELATIONS: Theories and Interventions

(with B. Featherstone, J. Hearn and C. Toft)

Also by Brid Featherstone

FAMILY LIFE AND FAMILY SUPPORT: A Feminist Analysis MOTHERING AND AMBIVALENCE (ed. with W. Hollway)

PRACTICE AND RESEARCH IN SOCIAL WORK: Postmodern Feminist

Perspectives (ed. with B. Fawcett, J. Fook and A. Rossiter)

VIOLENCE AND GENDER RELATIONS (with B. Fawcett, J. Hearn and C. Toft)

Also by Jim Goddard

STATE CHILD CARE: Looking After Children? (with C. Hayden, S. Gorin and N. Van der Spek) 


\section{Contemporary Child Care Policy and Practice}

\section{Barbara Fawcett, Brid Featherstone and Jim Goddard}




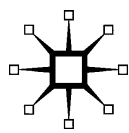

(C) Barbara Fawcett, Brid Featherstone and Jim Goddard 2004

All rights reserved. No reproduction, copy or transmission of this publication may be made without written permission.

No paragraph of this publication may be reproduced, copied or transmitted save with written permission or in accordance with the provisions of the Copyright, Designs and Patents Act 1988, or under the terms of any licence permitting limited copying issued by the Copyright Licensing Agency, 90 Tottenham Court Road, London W1T 4LP.

Any person who does any unauthorised act in relation to this publication may be liable to criminal prosecution and civil claims for damages.

The authors have asserted their rights to be identified as the authors of this work in accordance with the Copyright, Designs and Patents Act 1988.

First published 2004 by

PALGRAVE MACMILLAN

Houndmills, Basingstoke, Hampshire RG21 6XS and

175 Fifth Avenue, New York, N.Y. 10010

Companies and representatives throughout the world

PALGRAVE MACMILLAN is the global academic imprint of the Palgrave Macmillan division of St. Martin's Press, LLC and of Palgrave Macmillan Ltd. Macmillan ${ }^{\circledR}$ is a registered trademark in the United States, United Kingdom and other countries. Palgrave is a registered trademark in the European Union and other countries.

ISBN 978-0-333-97379-0 ISBN 978-0-230-00623-2 (eBook)

DOI 10.1007/978-0-230-00623-2

This book is printed on paper suitable for recycling and made from fully managed and sustained forest sources.

A catalogue record for this book is available from the British Library.

A catalog record for this book is available from the Library of Congress.

$\begin{array}{llllllllll}10 & 9 & 8 & 7 & 6 & 5 & 4 & 3 & 2 & 1\end{array}$

$\begin{array}{llllllllll}13 & 12 & 11 & 10 & 09 & 08 & 07 & 06 & 05 & 04\end{array}$ 
Dedicated to Kate and Sophie, Anthony and Áine 


\section{Contents}

List of Tables, Figure and Box $\quad x$

Acknowledgements $\quad$ xi

List of Abbreviations $\quad$ xii

1 Introduction $\quad 1$

The Social Investment State $\quad 4$

Broader Action on Child Welfare: Poverty and Education 6

Parents, Parental Responsibilities and the Rights of the Child 9

Tackling Social Exclusion through Targeting $\quad 12$

$\begin{array}{ll}\text { Structure of the Book } & 13\end{array}$

2 Thinking About Children Today 17

'Discovering' Children and Childhood(s) 18

Deconstructing 'the Family' $\quad 23$

Children's Rights $\quad 27$

$\begin{array}{ll}\text { Conclusion } & 29\end{array}$

3 Family Policy $\quad 31$

What is Family Policy? $\quad 31$

Pre-1997 - Pre-modern Panics 34

What has Happened Under New Labour? 36

$\begin{array}{ll}\text { Supporting Families } & 39\end{array}$

Discussion $\quad 41$

Parents and Their Responsibilities $\quad 43$

Are Things Getting Better then? $\quad 46$

$\begin{array}{ll}\text { Conclusion } & 49\end{array}$

4 Child Abuse and Child Welfare 51

Post-war Developments: The 'Welfare State' 52

Alternative Voices $\quad 54$

The Children Act $\quad 55$ 
Messages from Research - Reconstructing Child Abuse? 57

What has Happened under New Labour? $\quad 60$

Discussion $\quad 62$

The Child Protection System - Protecting Who from What? 64

Tensions in Practice $\quad 67$

$\begin{array}{ll}\text { Conclusion } & 69\end{array}$

5 Looked After Children $\quad 71$

Introduction $\quad 71$

Tackling Social Exclusion: Focusing on Looked After Children $\quad 73$

Past Policy towards Looked After Children $\quad 75$

$\begin{array}{ll}\text { Quality Protects } & 78\end{array}$

The Education of Looked After Children $\quad 80$

Leaving Care $\quad 81$

Parenting and 'Corporate Parenting' $\quad 82$

Children, Parents and the State $\quad 83$

Control, Regulation and Targeting $\quad 86$

Looked After Children: Reforms and Practice $\quad 88$

Discussion $\quad 90$

$\begin{array}{ll}\text { Conclusion } & 91\end{array}$

6 Youth Justice $\quad 93$

Introduction 93

From Old to New Labour on Youth Justice 95

Youth Justice and the Crime and Disorder Act 1998

Children's Rights and Youth Justice 105

Parents and Parenting 107

$\begin{array}{ll}\text { Targeting Children } & 109\end{array}$

$\begin{array}{ll}\text { Conclusion } & 111\end{array}$

7 Disabled Children and Young People $\quad 114$

Introduction 114

Social Inclusion and Citizenship: Work vs 'Care' 117

Investing through Parents: Support vs Surveillance 119

Investing in Children: Targeting vs Rights 123

$\begin{array}{ll}\text { Conclusion } & 128\end{array}$

8 Children, Young People and Mental Health 130

$\begin{array}{ll}\text { Introduction } & 130\end{array}$

Adult Mental Health Services: Debates and Policies $\quad 131$

Children, Young People and Mental Health $\quad 135$

Medicalised Perspectives 137

The Implications of a National

Service Framework $\quad 140$

Issues of Rights and the Potential for Conflict 141 
New Labour and the Mental Health of Children and Young People

Conclusion

9 Children as Carers $\quad 146$

Introduction 146

Notions of 'Care' and Definitions of 'Young Carers' 147

'Young Carers' and the Legislative Context 148

Investing in Children and Young People as Carers 149

The Contested Position of 'Young Carers' 150

The Implications for Children and Young People $\quad 154$

Conclusion 156

10 Conclusions $\quad 158$

Introduction $\quad 158$

Social Exclusion/Social Investment $\quad 159$

Children's Rights, Involvement and Autonomy 161

New Labour's Approach to Parents 162

The Role of the State 163

$\begin{array}{ll}\text { Conclusion } & 165\end{array}$

$\begin{array}{ll}\text { References } & 166\end{array}$

$\begin{array}{ll}\text { Index } & 183\end{array}$ 


\section{List of Tables, Figure and Box}

\section{Tables}

1.1 Some significant policy initiatives with respect to children, 1998-2003

5.1 Children looked after on 31 March 2002 by category of need

\section{Figure}

10.1 New Labour, children and the social investment state

Box

6.1 Crime and Disorder Act 1998: youth justice measures 


\section{Acknowledgements}

As always with a publication of this kind, the three authors have had help from a number of other people in the production of this book. Without their help, the book would have been a much harder task and a less complete work.

First, we would like to thank Sue Hanson at the University of Huddersfield for her sterling work in getting the manuscript into a finished state against fairly tight deadlines. We would also like to thank Professor Ruth Lister at the University of Loughborough, who provided helpful comments on an early version of the book. We have also benefitted from the feedback of academic colleagues at a seminar at the University of Huddersfield in February 2003 and at the Social Policy Association Annual Conference in Middlesbrough in July 2003.

Finally, we would like to thank Catherine Gray and Kate Wallis at Palgrave Macmillan, who have been unfailingly supportive as our work has proceeded. 


\section{List of Abbreviations}

ACPC Area Child Protection Committee

BV Best Value

CAMHS Children and Adolescent Mental Health Services

CPR Child Protection Register

CSP Children's Services Planning

DoH Department of Health

LAC Looked After Children

MAP Management Action Plan

OFSTED Office for Standards in Education

PSS Personal Social Services

QP Quality Protects

SSD Social Services Department

SSI Social Services Inspectorate

YOT Youth Offending Team 